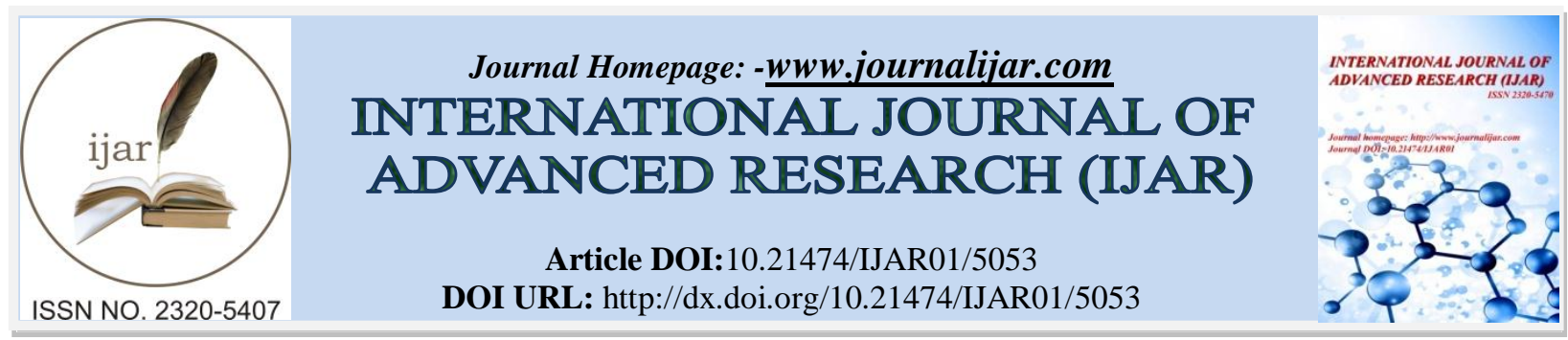

RESEARCH ARTICLE

\title{
DISSEMINATION OF SUSTAINABLE PRACTICES IN MOROCCAN AUTOMOTIVE INDUSTRY: CASE OF RENAULT-TANGIER.
}

\author{
A. Haddach ${ }^{1,2}$, M. Ammari ${ }^{1,2}$, L. Ben Allal ${ }^{1,2}$ and A. Laglaoui1 ${ }^{1}$. \\ 1. Abdelmalek Essaâdi University, Faculty of Sciences and Techniques, Tangier, Morocco. \\ 2. Research team: materials, environment and sustainable development.
}

\section{Manuscript Info}

Manuscript History

Received: 03 June 2017

Final Accepted: 05 July 2017

Published: August 2017

Keywords:

Sustainable Development, Automotive

Industry, Economic, Environmental,

Social, Morocco, Company, Renault

Group.

\begin{abstract}
In this article, we present the sustainable development approach of a large French multinational, the Renault group of Tangier. We will recall first some definitions of the sustainable development concept and we will specify the context of Moroccan automotive sector. The second part of our work will be devoted to the case study. Our work aims to show the developments which the company faces; in its local, national and international environment, and the answers that it brings in terms of its sustainable development approach. Some recommendations were issued to strengthen the sustainability of the automotive industry by adopting an integrated vision combining the role of automotive companies, public and public sector.
\end{abstract}

Copy Right, IJAR, 2017,. All rights reserved.

\section{Introduction:-}

Automotive industry has an important place in economy of many countries, by jobs creation and its beneficial effect on other economic sectors. Whether it is under state tutelage or under the direction of private sector, part of profits generated by automotive operations is reinvested in key areas such as education, health, infrastructures and many others. However implementation and development of automotive industry lead negative consequences on environment and society.

Following increasing pressure, automotive industry began to pay special attention to environmental and social impacts of its activities. This change was reflected by appropriation of sustainable development concept in automotive industry. Furthermore, ability of automotive industry to integrate sustainable development in its activities still disputed. Moreover, while society considers sustainable development as a necessity, industry often sees it as a compromise.

Research presented here is to better understand of the automotive industry practices in sustainable development domain. We chose to explore the case of Renault-Tangier group. Indeed, rather than dwelling to past mistakes, the goal is to use accumulated experience in the framework of an automotive company in order to build a vision of sustainable automotive development combining expectations of the population, public sector and automotive companies. First, we will present automotive sector in morocco and then define the conceptual framework. The third part of our work will be devoted to the case study of the Renault-Tangier group in a constantly changing economy. 


\section{Moroccan automotive industry:-}

2.1. Contribution of automotive industry in national economy:-

Moroccan automotive industry strengthens its position in the global value chain of automobile as evidenced by the remarkable performances recorded in recent years with an automobile production exceeding 167.450 vehicles in 2013 against 18.546 vehicles only in 2003. morocco became the second largest producer of vehicles in Africa [1] after south Africa with a market share of 26\% in 2013 against 5\% in 2003 and should be further strengthened with the entry into service of second tranche of Renault project carrying its total capacity to 340.000 vehicles [2].

Thus, exports of this industry have strengthened by $18 \%$ per year between 2008 and 2013, to reach over 30 billion dirhams with the prospect of making it to the front row of industrial export activities starting from 2014.similarly, skilled employment generated by the sector has evolved by $17 \%$ by year over the same period to stand at more than 80.000 jobs in 2013.

This position of morocco on the global value chain is the result of a series of efforts around a coherent and attractive automotive offer basing, in particular, on an efficient logistics around the tangier-med port, a targeted training offer , industrial infrastructures dedicated and some installation aids.in this context, it should be noted the important advances in the consolidation of this offer as evidenced by the scalability of Renault tangier project (industrial site among the cleanest in the world) with a production [3] which reached over 200.000 vehicles at end-2013.thus,this project will permit to improve significantly trade balance through increased industrial exports (more than 38.5 billion dirhams in long term).

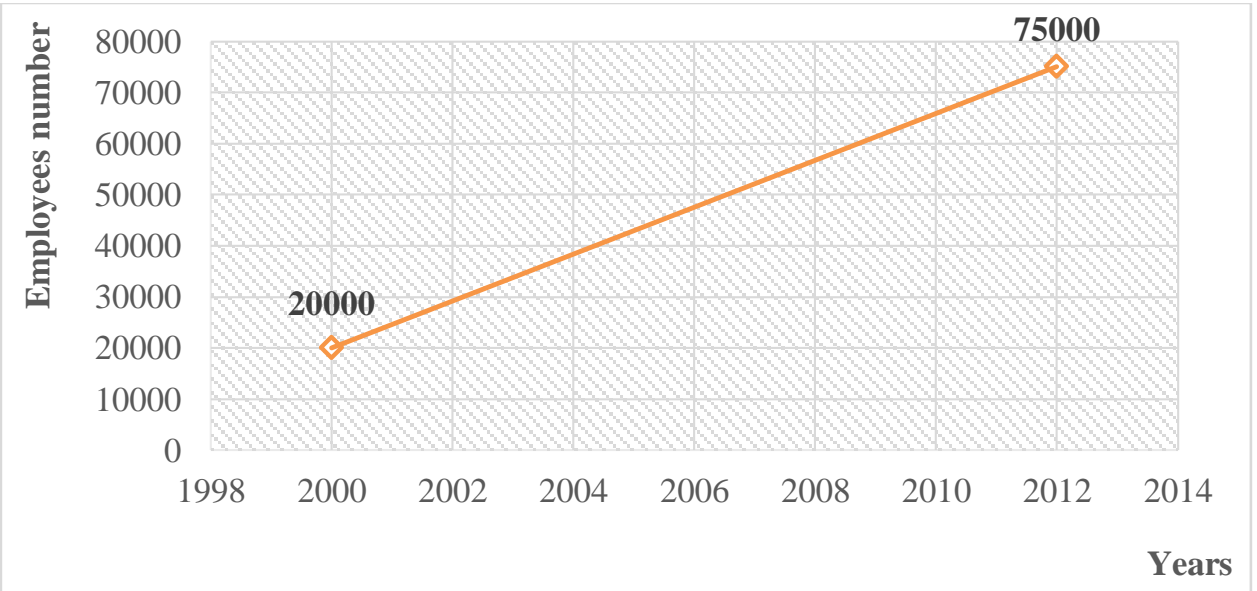

Fig. 1:- augmentation of employee's number in Moroccan automotive sector (2000-2012) [1]

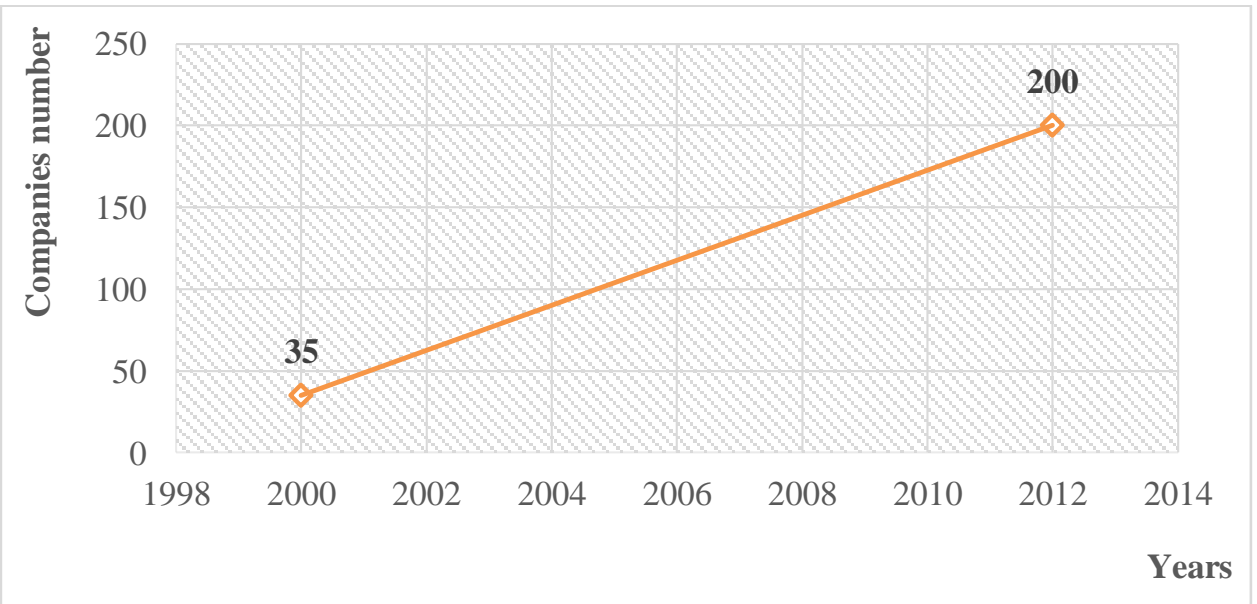

Fig. 2:- augmentation of company's number in Moroccan automotive sector (2000-2012) [1] 


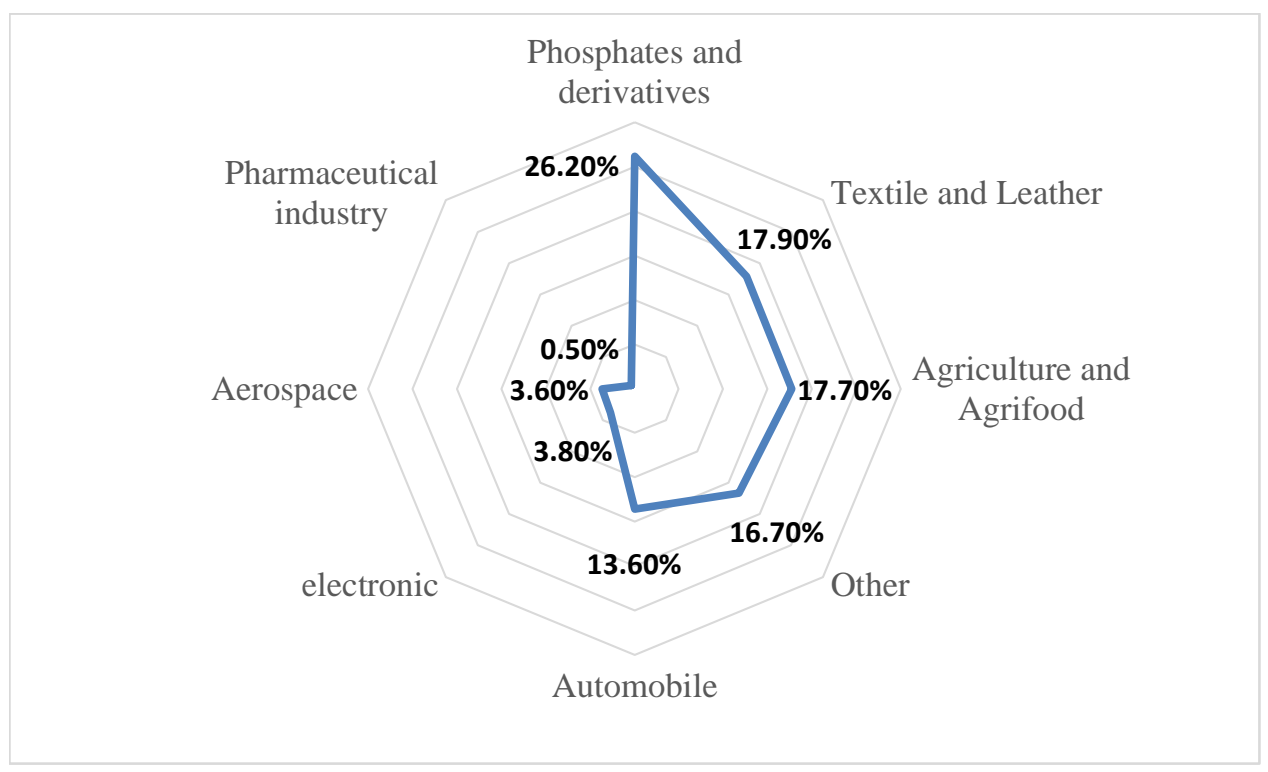

Fig. 3:- Moroccan exports by sector in 2012 (in\% of total exports) [2]

\subsection{Reforms of Moroccan automotive industry:-}

Moroccan automotive sector is strategic in the national industrial policy.it has been identified among the growth drivers in view of development which it has known in recent years. It presents even greater opportunities for the next decade. Morocco was one of the predecessor's African countries which implement an industrial policy for automotive sector in the aftermath of its independence, by the creation of the assembly line somaca in Casablanca in 1959.in addition, morocco has succeeded in consolidating the assembly industry with the redeployment of Renault in morocco and the installation of international equipment suppliers in its wake.

The Moroccan automotive sector is considered by government as a threefold strategic sector in terms of wealth creation, job creation and foreign exchange generation. Therefore, Moroccan government does not hesitate to get involved in its development. It shows the willingness to carry the sector, to structure it and to create the right conditions for its development. Moroccan government offers for investors some packages providing infrastructures, quality services, incentive framework and solutions of human resources training which they need.

The National Pact for Industrial Emergence (NPIE) designated automotive industry one of its key sectors. In September 2007, Renault has revealed a plan dedicated to the establishment of a new assembly plant for private cars in tangier with an annual capacity of 340.000 vehicles, and whose construction cost was estimated at 1 billion euro. Renault completed its initial construction phase and commissioned its first assembly line in February 2012, which has an annual capacity of 170.000 units. It is also reported that the company achieved in October 2013 the construction of a second production line which has the same capacity of 170.000 units per year, or 340.000 vehicles per year in total.

\section{Impacts of automotive industry:-}

Automotive industry activities emit various types of waste which can pollute air, soil, water, flora or fauna. These activities can henceforth harm environment due to emissions and noise resulting mainly from assembling of cars.

From social point of view, automotive industry activities cause sometimes relocation of populations (forced displacement of populations, rush of foreign workers into automotive business areas, abandonment of farming). Community structures can be weakened and cultural identity can be disturbed. Implementation of an auto plant can also cause health problems for surrounding populations.

Theoretical framework:-

\subsection{Sustainable development: foundations and challenges:}


Sustainable development has long been seen as a vague or complex concept. Nowadays and according to several research works, sustainable development is a concept which is based on an integrated approach, in which each economic development can’t be separated from social and environmental aspects.

Several definitions have been allocated to sustainable development. The broader and more widespread, was hyped by the famous brundtland report "our common future" of the world commission on environment and development, published in 1988, "sustainable development is a development mode which meets the present needs, while preserving the needs of future generations and especially the basic needs of the poorest who should be given the highest priority ... ".

This definition of sustainable development, like many others, refer to a macroeconomic scale.so, how can companies contribute to sustainable development?

Today companies evolve in different markets with different socio-cultural contexts. So, the role of company has expanded: it goes beyond the one economic vision which is limited to financial targets, but also includes social and environmental concerns.

Thus, the declination of the sustainable development principles at company's level was done through the corporate social responsibility (CSR) which several contributions addressed it. CSR has been defined in the report of the committee of European communities published in 2001 as "the voluntary integration of social and environmental concerns of companies in their commercial activities and in their relations with their stakeholders" [3]. Now, CSR notion is materialized through the triple bottom line concept: economic prosperity, environmental friendliness, respect and enhancement of social cohesion [4]. This concept translates the taking into account, in company scale, of the three major dimensions of sustainable development.

\subsection{Sustainable development in automotive industry:-}

Sustainable measures require investments in research and development of technical and managerial skills by the innovative agent, and require a significant period of time until they can be adopted as a new paradigm of production. The effort of a company to be sustainable generates costs that it hopes to recover through the benefits resulting from its adoption $[5,6]$.

Due to the pre-disposition to sustainability in big companies, the inclusion of environmental issues in the innovation process becomes relatively easier, considering the existence of a technical and managerial structure capable of incorporating changes in the production process pushed by the technological development itself of the activity [7].

The design, implementation and diffusion of environmental technologies in the automotive industry, says Christensen [8], are largely dependent on the current configuration of the productive system. Because car manufacturers are important for the environmental, social development of the world, in the context of sustainability. The automotive industry is relevant in terms of its impact on the economy as well as on technology. As stated by Humphrey and Memedovic [9], the automotive sector is global and is characterized as a capital-intensive industry with vertical integration and economies of scale [10]. It has been responsible for the development of technological innovation and management, and the original major change on the industrial production processes $[11,12]$.

For automotive industry, sustainable development means a quantitative and qualitative supply sufficient and affordable for all and forever in a healthy environment respecting biodiversity and socio-diversity, while remaining concerned about the fate of future generations.

To face significant challenges in transition to sustainable development, automotive industry has made significant efforts by taking into account environment and society in its objectives. So, a sustainable automotive development can translate into:

\section{An intergenerational equity:-}

Intergenerational equity is the responsibility of each generation to leave a legacy of sufficient resources for future generations to enable them to develop. It is a fundamental principle of sustainable development. Automotive companies search mainly the short-term economic fallen, while the communities are concerned about their long- 
term survival. Public sector can play an important role in pushing industry to respect sustainability principles, especially through laws and regulations which control exploitation intensity.

\section{Always a healthy environment:-}

Automotive activity generates environmental impacts, both during and after exploitation. We must prevent environmental damages, rather than repairing them afterwards.

\section{Communities well-being:-}

Automotive industry can have a significant participation in sustainable development communities, either directly through provision of jobs and services (education, health, etc.), or indirectly by contributing to development of other local companies. However, creation of a sustainable community heritage remains a big challenge [13] insists on a proper consideration of community expectations, which will help to improve trust between stakeholders and to minimize the conflicts [14].

\section{Empirical approach: case of Renault-Tangier group:-}

In order to better understand integration of sustainable development in Moroccan automotive industry, we have chosen to explore the case of Renault-Tangier group.

Sustainable development challenges are numerous for the group, and they are specific to its industry. The group favors a multi-local approach and multi-stakeholder, which is reflected by many actions and multiple partnerships. Consequently, this part of study will focus on the exploration of present state, then identification of sustainable development practices by Renault group and finally proposal of measures to promote commitment of sustainable development in automotive sector.

\subsection{Methodological framework:-}

In this research, we chose to study the case of a French multinational pioneer in sustainable development practices, Renault-Tangier group. We relied, to realize our study, on land data collected during an interview with an environment responsible within the group. The interview was aimed at knowing precisely: changes which the group has undergone in recent years and the actions of sustainable development and of CSR committed by this latter in response to these developments. It took place in an open, free interview guide, but structured around the called objectives. We obtained additional data by consulting several documents that allowed us to enrich data collection which was done also from several studies on the phenomenon in question (sustainable development in automotive sector).

This empirical research, exploratory, was aimed to better understand the changes taking place in the company's relationship with environment and society in general. Moreover, we believe that an analysis of a case such as Renault-Tangier group can provide generalizable elements to similar cases, to other automobile companies and possibly to other multinationals.

\subsection{Case study:-}

\subsubsection{Presentation of Renault-Tangier case:-}

Renault plant of tangier is dedicated to the production of Lodgy and Dokker models, from stamping to assembly through sheet metal and paint. The plant responds to local and international demand for entry-level models.

Inauguration in February 2012, of Renault-tangier factory was a turning point for automobile sector. One year after activity starting, the site has doubled its production and has manufactured over 100.000 vehicles. Plant became the second platform by its importance of "entry" range of Renault-Nissan, after the historic plant of Pitesti in Romania. Now, Tangier plant provides 5.500 positions against 4200 at the end of 2012, and should eventually reach about 6000 employees. Since the site opened in 2012, the Trades Training Institute for Automotive Industry (TTIAI) adjacent to Renault-tangier plant has surpassed one million hours of training. This center, whose infrastructure was funded by Moroccan state but whose operation is provided by Renault, has already trained more than 5.500 employees from Tangier plant. 


\subsubsection{Sustainable development practices and CSR of group:-}

Since its inception, Renault-Tangier plant was concerned about the environmental and social impact of automobile activity on its implementation territories. He spent sizable sums for civic actions destined to local communities and for environment preservation.

Sustainable development practices include:

\section{Social responsibility:-}

Sociocultural level:-

Considering the nature of his settlement area, Renault-Tangier group aims to position itself among the key players who contribute, directly, to socio-cultural development of the region. Convinced that access to mobility is indispensable to economic and social development, the group has made from this axis the conducting wire of its local roots strategy. Its action results in local communities through continuous and organized action for local residents.it concerns essentially the establishment of an effective and safe school transport device to help in fight against school dropout.

\section{Educational level:-}

The commitment of Renault group in morocco for education is concrete, with the aim to contribute to social mobility and promote meritocratic values. Actions carried out in this direction concern the coaching and training of deserving students in courses of higher studies. In fact, since 2012, the group supports the scholarship program of the Moroccan Foundation of Student (MFS). Since then, and for five years, three students receive comprehensive support in their higher education courses.

This individual support is driven by the top leadership of the group in morocco.

\section{Road safety level:-}

From its carmaker, Renault designs road safety as a right for all, but also as a strategic axis of its social responsibility.

The commitment of Renault group on the theme of road safety does not date from today.

Indeed, for several years, Renault launched and deployed, worldwide, innovative programs of education and awareness to road safety.

In this way and in the implementation of its road safety program with an innovative public-private partnership, Renault morocco group has gone further in its commitments by signing partnership agreements with with an active public bodies in road safety domain, namely:

1. Ministry of Equipment, Transport and Logistics.

2. Ministry of Education and Vocational Training.

3. General Directorate of National Security.

4. National Committee for the Prevention of Traffic Accidents (NCPTA).

b. Environmental responsibility:-

Environmental impacts of Renault-Tangier plant will be reduced to levels not seen for a bodywork assembly plant:

\section{Plant with zero carbon:-}

$\mathrm{Co}_{2}$ emissions from the tangier plant will be reduced by $98 \%$ (compared with an equivalent plant with a production of 400.000 vehicles), which corresponds to 135.000 tons of $\mathrm{co}_{2}$ avoided per year through optimization energy consumption and the use of renewable energies. The few remaining tons will be offset either by buying carbon credits or by generating renewable energy in situ.

\section{Plant with zero industrial liquid discharge:-}

Tangier plant will not issue any liquid industrial waste and will reduce by $70 \%$ its water levies for industrial processes compared to an equivalent plant of production capacity.

These results are due to:

1. Industrial processes optimization to reduce water requirements and to minimize corresponding discharges;

2. Use of advanced technologies developed by Veolia Environment to fully recycle industrial effluents. Several processing steps used to transform effluents to purified water (deionized); 
This water, meeting to quality requirements of process, is then reused to manufacture the vehicles. In total, equivalent of 175 olympic swimming pools $\left(437.500 \mathrm{~m}^{2}\right)$ will not be taken each year from natural environment.

\section{An electricity from renewable energies:-}

Through development of renewable energy in Morocco, Moroccan National Office of Electricity (MNOE) will provide $100 \%$ of electricity needs of the site by wind power, hydraulic, As part of group's commitment to sustainable development in northern region of morocco and to secure slopes present overwhelmingly around the tangier plant, this latter in partnership with regional directorate of water, forests and combat desertification of the Rif, launched the " planter mon arbre " operation.

This action was carried out at the hills around the tangier plant where sliding risk was present. Nearly 20.000 trees have been planted in Renault-Nissan plant in tangier since march 5, 2014, which 5406 trees planted by all site employees.

As such, employees of Renault-Nissan plant in tangier joined their forces during three days to create green areas around the site. Each participant was able to plant his tree while personalizing it, hanging a label bearing his name and the planting date.

"planter mon arbre" was an opportunity to fight against water erosion in the catchment area housing the RenaultNissan plant in tangier, in accordance with anti-erosion management plan developed by the regional directorate of water and forests and combat desertification of the Rif.

\subsubsection{Site certifications:-}

To date, all Renault websites bear the acronym ISO guarantor of the company's commitment to quality, environment, health, safety, ergonomics and working conditions. Commitment of Renault-Nissan plant in tangier was also to obtain various certifications including ISO 9001 for quality, ISO 14001 for environment, security label SMR (Renault Safety Label) and RHP label (Highly Protected Risk) to align standards of other Renault plants. It's done.

These certifications are a support to the group's strategy for the protection and safeguarding of environment and meeting customer expectations. They encourage group management to move forward the implementation of its sustainable development strategy.

In this case study, we believe that a commitment to sustainable development certification process can only strengthen the group's strategy. ISO 26000, published in November 2010, represents the first true international standard of corporate social responsibility.

\section{Towards a strengthening of automobile industry sustainability:-}

According United Nations Environment Program (UNEP, 2002), "if sustainable development is defined as the integration of economic, environmental and social considerations, an automotive project which is developed and operated with ecological and social acceptability could be considered as contributor to sustainable development. "

The various players in the automotive industry, in particular, local communities, employees, public sector at national and local level, suppliers, customers, unions, insurers, developers and shareholders, can all play an important role in the turn of this industry towards sustainable development. We were mainly interested in automotive company role, public sector (national and local) and population (local community and employees):

\section{Automotive companies:-}

Integration of sustainable development principles in automotive industry can be beneficial for both communities and companies and calls for CSR concept. In order that the adoption of environmentally and socially responsible practices will not affect company's profitability, CSR should contribute to manage risks in order to improve company's reputation strengthening its links with various stakeholders $[15,16]$.

\section{Public sector:-}

Public sector must play its role fully by framing automotive industry. It must also ensure a progressive legal framework to optimize socioeconomic benefits by minimizing environmental impacts. On other hand, it must also support innovation, research and developments related to sustainable automotive development. 


\section{Population (local community and employees):-}

People involvement of in decision making especially in relation to social acceptance in automotive projects, plays a very important role in strengthening of automotive industry sustainability.

\section{Conclusion:-}

Automotive companies are under more and more pressure to register in an environment respectful approach and contribute to sustainable development of communities by contributing to local capacities building and distributing profits fairly. To register in a responsible gait, automotive companies must identify and assess, first of all, the environmental, social and economic impacts which may arise from exploration phase in order to enforce mitigation measures, in collaboration with concerned communities.

In this work, we presented the sustainable development and CSR gaits of a large French multinational: Renault group of tangier. In front of multitude changes, company has developed a new management mode aiming overall improvement of its performance by integrating interactions between economy, nature and society. This company appears as a committed firm which recognizes its responsibilities towards common good.

Finally, it remains to point out that to strengthen the sustainability of Moroccan automotive sector, other actors especially public sector (national and local) and population (local community and employees) must fully assume their responsibilities.

\section{References:-}

1. Moroccan agency for development of investments, 2013

2. Moroccan exchange office Livre vert, "promouvoir un cadre européen pour la responsabilité sociale des entreprises", juillet 2001.

3. Pesqueux, y., simon, e., vasconcelos, i. « l'entreprise durable et le changement organisationnel». L'organisation innovatrice et durable.editions ems .2014.

4. Belz, f.m.; schmidt-riediger, b. Marketing strategies in the age of sustainable development: evidence from the food industry. Bus. Strategy environ. 2010, 19, 401-416.

5. Fang, k.; uhan, n.; zhao, f.; sutherland, j.w. A new approach to scheduling in manufacturing for power consumption and carbon footprint reduction. J. Manuf. Syst. 2011, 30, 234-240.

6. Farias, a.s.; costa, d.s.; freitas, l.s.; cândido, g.a. Utilização de eco-inovação no processo de manufatura de cerâmica vermelha. Rai rev. Adm. Inov. 2012, 9, 154-174.

7. Christensen, t.b. Modularised eco-innovation in the auto industry. J. Clean. Prod. 2011, 19, 212-220.

8. Humphrey, j.; memedovic, o. The global automotive industry value chain: what prospects for upgrading by developing countries. 2003. Available online: https://papers.ssrn.com/sol3/papers.cfm?abstract_id $=424560$

9. Schulze, a.; macduffie, j.p.; täube, f.a. Introduction: knowledge generation and innovation diffusion in the global automotive industry - change and stability during turbulent times. Ind. Corp. Chang. 2015, 24, 603-611.

10. Casotti, b.p.; goldenstein, m. Panorama do setor automotivo: as mudanças estruturais da indústria e as perspectivas para o brasil; bndes setorial: rio de janeiro, brazil, 2008; pp. 147-187.

11. Barros, d.c.; castro, b.h.r.d.; vaz, 1.f.h. Automotivo. In panoramas setoriais: mudanças climáticas; banco nacional de desenvolvimento econômico e social: rio de janeiro, brazil, 2016.

12. Ballet, j., dubois j.-l. Et mahieu, f. « à la recherche du développement socialement durable : concepts fondamentaux et principes de base ». Développement durable et territoires 2004. Available online: http://developpementdurable.revues.org/11 65.

13. Kemp, d., owen, 1. R., gotzmann, n. Et bond, c. G.«just relations and company community conflict in mining». Journal of business ethics101: 93-109. 2011.

14. Sayer, j. «do more good, do less harm: development and the private sector». 2005.development in practice 15: 251-268.

15. Hopkins, m. « corporate social responsibility: an issue paper ». Working paper 27. Policy integration department, world commission on the social dimension of globalization, international labour office, genève. 2004. 